\title{
Association of haptoglobin genetic polymorphism with overall survival in advanced castration- resistant prostate cancer patients with personalized peptide vaccination
}

Nobukazu Komatsu ${ }^{1 *}$, Xiaoliang Pang ${ }^{2}$, Hiromitsu Araki ${ }^{2}$, Yoshiro Koda ${ }^{1}$, Kimiko Soejima', Tetsuro Sasada ${ }^{1}$, Kosuke Tashiro², Satoru Kuhara², Kyogo Itoh ${ }^{1}$

From Society for Immunotherapy of Cancer 28th Annual Meeting

National Harbor, MD, USA. 8-10 November 2013

Although a peptide vaccination is potentially useful for cancers, there are some patients who do not show clinically beneficial response to this treatment. Previously, we have demonstrated gene expression profiling of prevaccination peripheral blood mononuclear cells in advanced castration-resistant prostate cancer patients

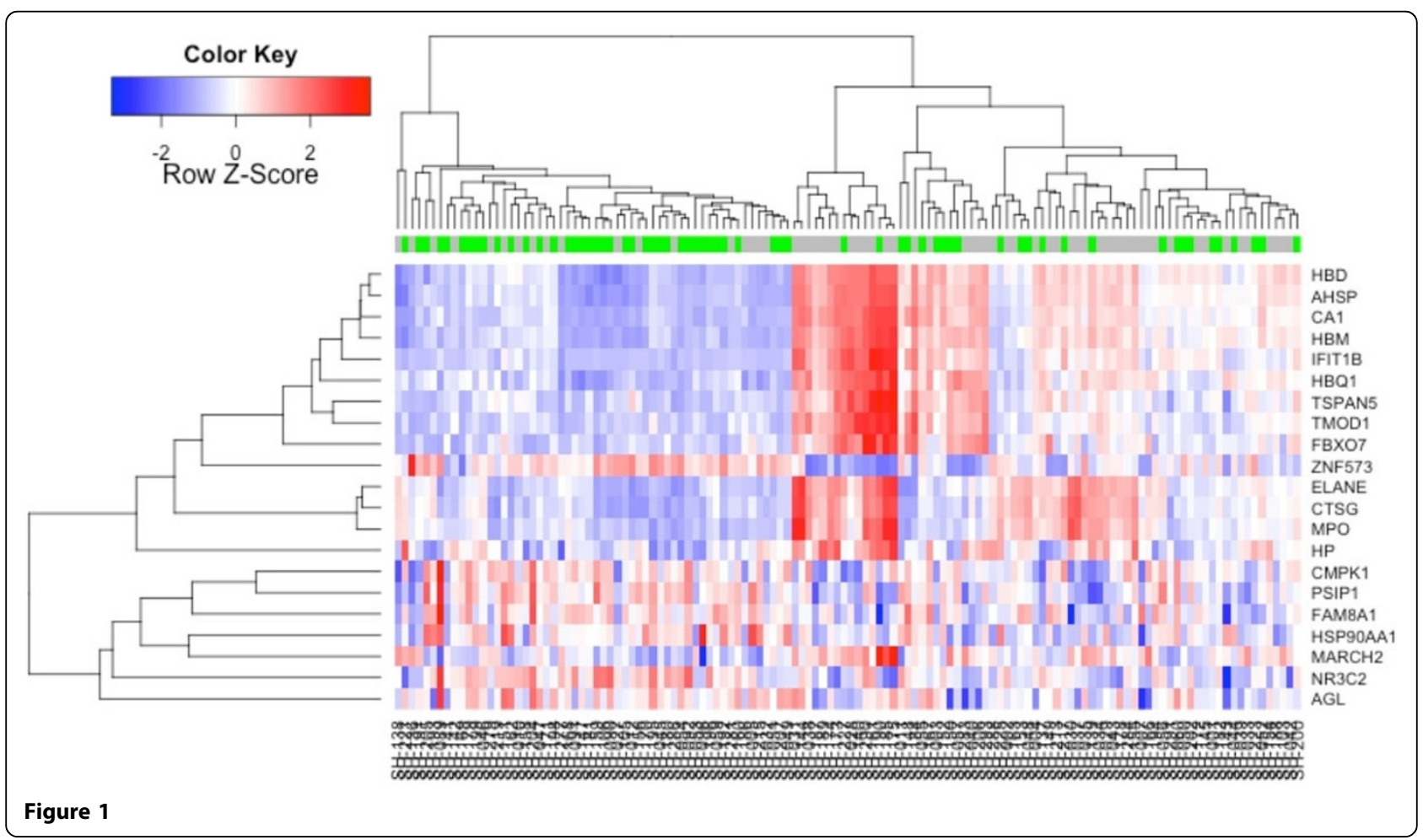

${ }^{1}$ Kurume University, Kurume-shi, Japan

Full list of author information is available at the end of the article 
with personalized peptide vaccination, and we have found some genes related with overall survival. In this study, we sequenced the upstream region of Haptoglobin (HP), which is the most significant q-value in a univariate Cox regression analysis $(\mathrm{q}$-value $=0.001)$ and highly expressed in patients with poor clinical response. Genetic polymorphism of the upstream of HP was identified and this polymorphism classifies patients with good or poor clinical response to a peptide vaccination. Our results suggested that mRNA level and genetic polymorphism of HP is related to the prognosis of advanced castration-resistant prostate cancer patients treated with peptide vaccination.

\section{Authors' details}

${ }^{1}$ Kurume University, Kurume-shi, Japan. ${ }^{2}$ Kyushu University, Fukuoka-shi, Japan.

Published: 7 November 2013

doi:10.1186/2051-1426-1-S1-P56

Cite this article as: Komatsu et al: Association of haptoglobin genetic polymorphism with overall survival in advanced castration-resistant prostate cancer patients with personalized peptide vaccination. Journal for ImmunoTherapy of Cancer 2013 1(Suppl 1):P56.

Submit your next manuscript to BioMed Central and take full advantage of:

- Convenient online submission

- Thorough peer review

- No space constraints or color figure charges

- Immediate publication on acceptance

- Inclusion in PubMed, CAS, Scopus and Google Scholar

- Research which is freely available for redistribution

Submit your manuscript at www.biomedcentral.com/submit 